Copyright (C) 2021 The Author/s

This work is licensed under a CC-BY 3.0 License

Peer review method: Double-Blind

Accepted: August 11, 2021

Published: September 21, 2021

Review article

DOI: https://doi.org/10.47305/JLIA2137310o

\title{
A PRUDENTIAL PERSONALIST ETHICAL APPRAISAL OF HUMAN CLONING
}

\author{
Peter O.O. Ottuh \\ Department of Religious Studies and Philosophy, Delta State University, Abraka, Delta State, Nigeria \\ ORCID iD: http://orcid.org/0000-0002-3587-7537 \\ ottuhpeter@gmail.com
}

\begin{abstract}
Numerous uncertainties are hanging over the biotechnology of human cloning which has prompted medical ethicists and religious organizations to ask questions that bordered on its ethical and religious considerations. In cloning humans, ethical and religious issues arise both in its clinical and laboratory settings hence, the morality of manipulating human genes is the foremost ethical issue among scientists and religious scholars. Therefore, this paper evaluated the human cloning technology using the personalism and prudential personalism ethical-religious models to arrive at a workable moral paradigm. To achieve this objective, the paper employed the phenomenological and critical-literary literature review methods. The paper argued that previous ethical and religious researches have not adequately employed the 'ideal' ethical models to appraise the morality of human cloning hence; using the personalism and prudential personalism ethical-religious models were appropriate to reveal that every human life has worth and its commodification is an aberration. The paper concluded that based on the paradigm of prudential personalist ethics, cloning humans (especially, human reproductive cloning) negates respect for human life, human dignity, and communal goods hence it should not be practiced.
\end{abstract}

Keywords: Human Cloning; Personalism; Prudence; Ethics

\section{INTRODUCTION}

One controversial issue in contemporary times that has generated serious ethical and religious debates is cloning, especially human cloning. Many authors have written on cloning, particularly on cloning a human. While some authors wrote to support the technology, others have written to express their disapproval. New areas of science have often subjected the safety of this technology to serious debates. For instance, the cloning of animals such as cows in the early 1990s that led to their development of abnormal immune systems attracted massive attention. It was also discovered in some cases that animal clones are likely to develop faster, grow old very fast, and die at a younger age than other counterparts of the same species. As a result of the potential dangers posed by this technology, some concerning scientific, religious, and world bodies such as the National Academy of Sciences (NAS), National Pro-Life Religious 
Council (NPRC), The President's Council on Bioethics (PCB), American Academy for the Advancement of Science, and United Nations Educational, Scientific, and Cultural Organization (UNESCO) among others have called for a total ban and non-legalization of cloning human beings (NAS 2002; PCB 2007; NPRC 2007; UNESCO 2006). The premises of their caution on cloning humans were bases on the observed high index of ill-health in animal clones which shows that the same ill-health will befall human clones including the egg-donors.

Human cloning also raises some religious and ethical issues. In 2001 when the first human embryo was cloned, it was met with serious objections by some religious groups. For example, the Roman Catholic Church (RCC) and other religious groups vehemently condemned the scientific enterprise and advocated its ban and nonlegalization holistically (Catholic Leadership Conference 2001). While some people believe that scientific advances that enable human cloning are a God-given blessing, others claim that cloning humans by scientists are playing God via human genetic manipulation.

Most opponents of cloning argue that cloning humans are anti-theism, anticreationism, anti-human and anti-society. To them, human cloning lacks ethical consideration and human morality. They refer to cloning humans as a scientific project that indicates fetal decay and deviation to which science is driven. They further argue that cloning human beings is a reflection of the authentic malaise of modernization which prizes science and technology far above human life.

While opponents of human cloning do not see anything good in it, its proponents argue that it has several benefits including preserving the human species and amelioration of human sufferings. Though their arguments have scientific and economic bearings they lack authentic ethical/moral judgment. Thus, to take care of these inadequacies, this research is aimed at evaluating the technology using ethicalreligious underlying principles to arrive at a workable moral paradigm. The underlying ethical and religious models adopted for the evaluation are Personalism and Prudential Personalism.

\section{CLONING: DEFINED AND DESCRIBED}

A 'clone' is a living thing created asexually from one ancestor. In biological science, the term implies an organism created from other organisms via splitting or cell differentiation which is different from those organisms that are created through sexual reproduction (Polkinghornme 1997; Ottuh 2010). The method of reproducing asexually in plants includes budding, grafting, layering, cutting, and splitting of plant rootstocks. Lower animals can also be produced through asexual reproduction, for example, Hydras, flatworms, etc. In higher animals, clones can also be created. Even nature creates clones, for example, identical twins or triplets. For Marclono (1998; Ottuh 2010a; Liu, Cai, Wang, 
Nie, and Zhang 2018), cloning is a method through which identical organisms are reproduced, that is, with similar genetic coding (Deoxyribonucleic acid or DNA) as the organisms that preceded them. Cooke (1977) and Thomas (2013) simply define cloning as the use of single identical cells to create a line of an exact duplicate of mature individuals. The above definitions imply that cloning is a form of reproducing asexually or regeneration since it is devoid of fertilization of the female egg by the male sperm, but the process is perfected via the method of autogenesis (self-creation) or electrical programming. Generally, every clone looks genetically.

Cloning means the manipulation of chromosomes from human or animal cells to produce an identical copy of an organism by inserting the adult nucleus into an egg from which the nucleus has been removed, stimulating embryogenesis, and implanting the embryo into the uterus of a surrogate mother (Daley and Solbakk 2011). The above definition best describes human cloning.

Cloning also means the creation of multiple identical living organisms that are genetically alike by substituting a nucleus or by mechanical division of a cleaving zygote to yield identical cells each of which can result in a new separate individual. Scientists have claimed to have successfully cloned sheep, mice, goats, cocas, pigs, and mules using the procedures described above (Liu, Cai, Wang, Nie, and Zhang 2018). The accelerating successes of scientists' experiments have led to widespread discussion over the possibility of human cloning.

McKinnel (1997) asserts that the most common scientific models for cloning are mice, fruit, flies, and frogs. According to him, in the history of unicellular organisms cloning, the first organisms to be cloned using nuclear transfer were frogs. The reason for this is that unicellular organisms have large egg cells and that scientists can obtain larger numbers of them from one ovulation. According to McKinnel, research cloning is also occurring in primates. The reason for this is the similarity they share with human beings. He further asserts that this trend has led many to the most talked about aspects of cloning- the use of the techniques with human cells and eggs. McKinnel's work though scientifically objective did not discuss extensively, the ethical, legal, moral, and religious-theological perspectives of cloning. While advocating a non-ban position on human cloning, he calls for centralized control and management of the technology.

On their part, Hawley (1997) and McLaren (2000) describe cloning as the production of two or more genetically identical individuals by mechanical division of cleaving Zygote to yield cells each of which can form a new individual. Cloning is the process of producing a living creature using the DNA from a single individual rather than the DNA from two folks, which is the most common practice among bisexual reproducing species (Begley 1997; Ottuh 2010b). Hawley says that an elaboration on the history, techniques, ethics, and purposes for researching cloning is necessary to avoid erroneous opinions about it. According to him, the lack of knowledge on the subject has led to variant opinions about it. 
Thus, a 'clone' is described as an organism that is asexually derived from a single individual by cutting, bulbs tubers, fission, or parthenogenesis. In his work, Appleyard (1998) refers to cloning as a biological (or botanical) term otherwise known as vegetative propagation which involves the use of small cuttings. This implies that the phenomenon of cloning has been going on in the natural world. Appleyard describes the success of man in cloning invertebrate organisms, adult animals, and the attempts to clone humans as a scientific stride. He calls for caution on the new trend but insists that human cloning is ethical. Appleyard's position favors therapeutic cloning. For Appleyard, cloning will be beneficial to humans economically or agriculturally, but beyond its economic values, it tends to alter the meaning of humanity and life, including divine creationism. Judging from Appleyard's work, the morale of scientists is boosted, while neglecting moral judgment on the subject, especially its implications.

Ottuh (2020) and Ayala (2015) explain the somatic cell nuclear transfer used in the successful cloning of Dolly the Sheep and pointed out that technological breakthroughs had led to possibilities of cloning humans. Concerning the scientific and biomedical implications of cloning, Qui (1997) thinks that the techniques can improve the health of humankind. Qui sees no problems with the cloning of human beings. He identifies two problems that are associated with cloning, especially animal cloning. This includes possible infections and tumor formation which are harmful to human beings. His concluding remark is that cloning is good, but it is not morally desirable to clone human beings. The morality of cloning is not well defined and stated by Qui.

On the other hand, Samson (cited in Annas, Andrews, and Isasi 2002) defines cloning as a scientific technique that involves the production of a genetic copy of an already existing organism, an animal, plant, or human. She explains that cloning can also mean the making of a genetic duplication of a DNA sequence, a cell, not just the entire organism. Ann's definition of cloning is complex since a clone is believed to be a complete offspring of its donor parent. Here, Ann distinguished between two types of cloning namely research or therapeutic and reproductive cloning.

According to Annas, the laboratory processes involved to create a cloned embryo in these two typology are almost the same. The difference between the two types of cloning has led to numerous debates around the control of scientific development in this area. In Ann's view, the rejection of research like human cloning that would lead to human medication is unethical and amounts to science fiction. As a proponent of human cloning, Ann forgot to realize that cloning will contribute to a grossly widening gap in living standards between the rich and the poor people and even nations. Annas also forgot to realize that such technology focuses mainly on the needs and desires of the wealthy few. Kolata (1997) writes on the evolutionary history of cloning where he traced the history of cloning to 1952. According to him, the first implantation of a nucleus into an egg cell by Robert Briggs and Thomas King took place in Philadelphia. 
Although this was not successful, the successful cloning of embryo cells was accomplished later in the 1970s by John Gurdon. There were other attempts until July 1997 when at the Roslin Scientific Institute a lamb number 6LL3 called Dolly was born through cloning (Campbell, Wilmut, Schnieke, McWhir, and Kind 1997; Ottuh 2010c). In Kolata's opinion cloning would directly offer a means to cure diseases or a technique that could extend the means to acquiring the development of organisms as a whole.

As a cloning proponent, Kolata never saw anything wrong with cloning, especially animal cloning. For Kolata, the cloning of livestock will help in the production of biological proteins that will help people who have diseases like diabetes, Parkinson's, and cystic fibrosis. Benoit (1996) and Wills (1998) agreed with Kolata that cloning animals like pigs and cows will assist in the production of human spare parts for human medication. They also argue that human cloning will enable infertile couples to raise their children. This will be made possible through the establishment of fertility clinics whose aim will be to clone embryos and even test them for genetic disorders. If an embryo is tested negative for genetic disorders, the clinic will then implant a clone of that embryo (Flock 2007). To achieve this, a frontline proponent of cloning and embryologist, Richard Seed claims that he has set up a fertility clinic that can conduct the nuclear transfer. The most amazing about the opinion of Kolata, Wills, and Benoit, including Richard Seed, is that they only based their judgments on the calculative gains

of cloning without taking into consideration the negative effects and gross losses that the technology would result. To these persons, every form of cloning is ethical since it would be of good to human society. There are three types of human cloning. They include embryonic cloning, reproductive cloning, and therapeutic cloning. However, the scope of this paper is limited to human cloning.

\section{RELIGION AND CLONING}

Towards understanding an ethical evaluation of human cloning within the contexts of Personalism and Prudential Personalism, it is paramount to reflect briefly on the history of the debates between religion and human cloning over the years. It is possible to identify four overlapping time frames in this wise, in which theologians, religious thinkers, and philosophers have engaged the scientific prospects and ethics of human cloning.

The first phase of discussion took place in the 1960s (Campbell 2002). This early debate was occasioned by a context of expanded choices and control of reproduction, for example, availability of the birth control pill, the prospects of alternative, technologically assisted reproduction, for instance, In-Vitro Fertilization (IVF), and advocacy by prominent biologists and geneticists of cloning 'preferred' genotypes to avoid over flooding the gene pool of humans with harmful genes thereby exposing human species' survival at great risk. Prominent among the theologians that initially 
participated in the debate concerning genetic manipulation and human cloning were Charles Curran, Bernard Haring, Richard McCormick, Karl Rahuer, Joseph Fletcher, and Paul Ramsey. Joseph Fletcher and Paul Ramsey stand out prominently to object and foresaw a world of cloning humans that is significantly prescient, given the level of present debates (Campbell 2002).

For Fletcher (1979), the cloning of human beings is a choice technique of reproduction that is related to the genetic roulette of sexual reproduction. Ramsey, on the other hand, sees cloning as a borderline or moral boundary, for medication that may be aligned at risk of compromising with human beings and procreation (Fletcher 1979; Ottuh 2020). He identified three horizontal border-crossings (person to person) and two vertical border-crossings (person to God) of human cloning to include the followings:

- Clonal reproduction requires a dictated breeding to serve a scientific end of a dictated gene poll.

- Cloning may involve non-therapeutic experiments on the potential human person.

- Cloning may negate what parenthood stands for by transforming procreation into reproduction and by altering the meaning and procreative ends of human sexuality.

- Cloning from the theological point of view represents the sin of pride and selfcreation in which humans aspire to become human-God (Verhey 1994; Ottuh 2010c).

The second time frame of theological and philosophical discussions on human cloning began in 1978, which is notable for two distinctive events: The birth of the first IVF baby-Louise Brown and the publication of David Rorvik's 'In His Image' (1978), an account alleging the creation of the first human clone (Ramsey 1970). While Christian theologians concentrated on the ethical issues raised by IVF, Jewish scholars such as Seymour Siegel and Fred Rosner directed attention to human cloning and were neither as supportive as Fletcher nor as indicting as Ramsey (Rorvik 1978). The first known and formal official response by protestant denominations to the discussion on cloning came in 1977 through the United Church of Christ. This ecclesiastical group provided a general overview of the science and ethics of human cloning through its work titled: 'Genetic Manipulation' (Lynn 1973, 74).

Other religious bodies in this period like the World Council of Churches in 1975, 1982, and 1989 and the National Council of Churches of Christ (1980, 1983, and 1986) among other religious groups also made their positions known giving cautious approval only to genetic interventions for therapeutic ends (Lynn 1973; Ayala 2015). In 1979, responses by some religious leaders on genetic engineering led the then-American President, Jimmy Carter to order for an evaluation of the scientific, ethical, and social 
issues of gene splicing by the President's Commission for the Study of Ethical Problems in Medicine and Biomedical and Behavioural Research.

The third era was in 1993 after the blastomere separation of human embryos at George Washington University sparked off mixed reactions (Campbell 2002). Firstly, the Roman Catholic Church expressed vigorous opposition, with the Vatican editorial faulting the findings as basically irrational (McCormic 1993; McLaren 2000). The conservative Protestants also held that the findings stand at variant at their basic concepts of personhood and humanity. Other Protestant scholars recognized the potential medical advantages from the findings and called for control rather than its ban.

The fourth and most recent stages of theological discussions came in the wake of the successful cloning of Dolly the Sheep. Here, the Catholic and Protestant groups restated their former positions (Shannon 1994; Ottuh 2010d). For instance, a Protestant theologian holds that an account of the good life in a family is inhospitable to cloning (Verhey 1994). On the contrary, some other Protestant theologians, reflecting on the weaning of human partnership with ongoing divine creative activity, have expressed qualified support for cloning research and human cloning. The report presented to the US National Bioethics Advisory Commission (NBAC) in 1997 provided the most considerable positions of theological evaluation in this revived debates on the ethics and morality of cloning research including its applications to human cloning (Verhey 1995; Arias 2010). Multiple but normative conclusions can be drawn from the above brief historical overview of religion and human cloning as follows:

- Sustained theological and philosophical debates on the issue of cloning with the intent to anticipate and promote robust current debates on the subject.

- The evidence that there is no singular theological and philosophical position on human cloning. In most cases, theological and philosophical positions exhibit societal pluralism.

- Despite changes in scientific undertaken and technical prowess, the values that underlie theological and philosophical concerns about human cloning have shown durability and staying power and have created general awareness and discussion on the subject.

- Religious discussion is no longer limited to professional theologians. It has expanded to encompass other professionals, including scientists, and other faiths, as well as education of religious adherents (Ottuh 2010c; Thomas 2013). This means, that theological and religious stances have gradually aspired and progressed to be informed communities of moral discourse on issues of reproductive and genetic technologies. 


\section{RELIGIO-ETHICAL REACTIONS TO HUMAN CLONING}

Post (1997) examines the reactions of religious organizations to human cloning. He says that religious organizations think that cloning by nuclear transfer could cause men to be reproductively obsolete. That cloning defies the rules or belief that humans have souls. Arguing along this line, James Hefley in 'Human Cloning: Playing God or Scientific Progress?' says that human is taking the work of God into his own hands. Their arguments include the determination of a clone's moral rights, the alteration of the very meaning of humanity, and the lack of perception of human uniqueness. Putting all these factors into consideration, Post and Hefley seem to be suggesting that human cloning is unsafe, anti-creationism, unethical, and anti-human. This view seems to represent the general opinion of anti-cloning groups, especially, that of religious organizations, for example, the Catholic Church (Catholic Leadership Conference 2001). This work is not objective enough because not all religious arguments for or against human cloning were discussed. Besides, the arguments of the various religious groups were not well articulated. Using a particular religious view to generalize judgment on human cloning is unhealthy and irrational. This is why; this study will undertake a theological-religious discussion on cloning, cutting across virtually all major religions of the world.

An author such as Cole-Turnner (1997) examines the divergent views of some of the major religions including Islam, Christianity, Judaism, Raëlism, Hinduism, etc. In summary, the majority of these religions seem to tow the same line that non-human and human cloning is unethical and anti-religious. Cole-Turnner's work is a compilation of responses by some religious groups. He did not only document the responses but also evaluated them with a view of arriving at a workable synthesis concerning the rightness or wrongness of human cloning.

Still, on the religious perspective of human cloning, two religious panelists Zoloth and Holland (2001) began their debate with a discussion on protestant ideas about the sin of pride and respect for persons and how these apply to human reproductive cloning. Giving current safety concerns on cloning, they favor a continuing ban on cloning. But ultimately, they argue that cloning should be regulated rather than banned outrightly. On their part, Zoloth and Holland reached a different conclusion about reproductive cloning based on her reading of Jewish sources. Among the Jewish sources, she cited is the view that the world is an uncompleted "whole" that needs human participation to become a "total whole", and the fact that human cloning promotes religious compassion and charity. They fail to realize that the negative impact arising from the technology will at the same time lead to human sorrow and disabilities. For instance, Whilmut (in Ramsey 1997; Wilson 2014) says that it took 277 attempts to clone Dolly successfully. These failures suggest death and losses. To take care of these inadequacies, this study therefore will strike a balance between the positive and negative impact of cloning humans both on people and on the society-at-large. 
Among works that discuss the relationship between bioethics and religion include that of John Mahoney (1984) where he explores in-depth the possibility of a dialogue between Christianity and medicine regarding In-Vitro Fertilization and other forms of assisted reproductive issues. Others in this series include 'Theology and Bioethics: Exploring the Foundations and Frontier' written by Earl E. Shop which contains twenty essays on theology, science, bioethics foundations and frontiers in religious bioethics, religious reasoning about bioethics and medical practices (Shelp 1986; Ayala 2015; Enwere 2002; Zahir 2016). All these works set the basis for ethical-religious arguments against human cloning and forms of assisted reproductive practices. These arguments are sound and appealing especially as they support human respect and dignity.

'Congregation of the doctrine of faith: Instruction on respect for human life in its origin and on the dignity of procreation' (1987) contains the Vatican's position on human cloning and other medically assisted reproduction. The work traces the origin of life and that of procreation. Here, the origin of life is traced to God. And procreation traced to human sexuality. It advocates priceless respect for human life and human dignity. This work in its entirety suggests that human cloning in all its forms is a negation of respect for human life and human dignity. This is another religious argument against human cloning.

The World Council of Churches (WCC) working group examined the ethics and the biological sciences as they relate to human cloning (World Council of Churches 1979). WCC believes that cloning raises some ethical objections similar to those of positive eugenics. According to the WCC, there is no societal, let alone global, consensus on 'superior' human qualities, and that cloning technology places enormous powers of manipulation in the hands of a few experts, who require control by other experts.

It is contended that the fundamental issue of cloning is the sanctity of human life (Anderson 1982). This is because; the potential for loss of life and genetic abnormality is very high in cloning. Anderson argues that, while clones would be creations in God's image and have souls, the major question is whether their humanity would be redefined. Because of societal disregard for the sanctity of life, clones will likely be used for spare parts and be abused by clonists and clonees. Anderson posits that cloning is anti-human and anti-society. In the same vein, Breek (1991) contends that cloning science holds out tremendous promises for agriculture, but that religions must condemn it as a grotesque manipulation where it is to be practiced on human beings.

Brown (1995) focuses on human personhood and the principles of the image of God. According to Brown, the principles of the image of God give a decisive command to the person for the prohibition of "creative genetic predetermination of a human being" through cloning or chimeras because human freedom is denied, respect for life is disregarded, and the relational self is violated. Brown contends that human freedom for self-determination is theologically subject to the image and sovereignty of God (Tugnoli 
2016; Duff 1997). Several reasons against cloning from a theological perspective are presented to include the followings:

- Cloning represents an insidious form of pride, in as far as we may seek to create more perfect humanity or humanity created after our image. He argues that power to create humans means power over human beings.

- Human beings are not their creators, but cloning raises more prospects of humanity acting as its destroyer.

- Human cloning may challenge traditional forms of human procreation.

- There is a potential risk of harm to the identity of the cloned child.

- The presumed ownership and manipulation of animal life for human cloning may violate the theological claim of dominion. For these reasons, Duff calls on the Church to forge a responsible path for this new technology (Duff 1997).

Within Hindu spirituality, it is believed that one should ask of and embrace cloning technology. A Hindu would ask, will this help me in my search for realizing God, who is enshrined in the depths of my consciousness? For Hindus, cloning science is an answer to this question. It is argued that the real moral question is not whether or not to engage in cloning, but when and why (Fletcher 1997). Fletcher replies that there is no ethical objection to cloning when it is morally or humanly employed and practiced. Fletcher portrays cloning as one among many methods of reproduction useful under appropriate circumstances. It can alternate with sexual reproduction as need suggests, in one generation or another. He asserts that the criteria of humanness, laboratory reproduction is radically human because it is rational and deliberate. Human beings should exercise the same kind of reproductive choice and control over themselves as they do over non-humans. According to Fletcher, what humans can do by cloning plants and animals they could and sometimes should do for themselves. Among humane uses of cloning technology according to Fletcher are:

- Providing 'clonants' (i.e. instructively, Fletcher never uses the language of the 'person') with sources of immunological compatible life-saving organs.

- Perpetuation of the finest genotypes in the human species.

- Cloning a child's sex to avoid a genetic-linked disease or to ensure family survivalism.

- Selective reproduction of individuals, e.g. to scientists, for social vocations that require specific characteristics.

- Reparation of a diminishing human gene pool;

- Safeguarding those (e.g. soldiers, space travelers, etc.) who assume risks or dangerous roles on behalf of human society.

Arguing from the Islamic perspective, Hathout (1997) says that the Qur'an and Islamic traditions encourage scientific inquiry; hence, scientific knowledge becomes a 
symbol or sign of God's creation. Cloning, according to Hathout, imitates creation by manipulation of elements created (Khaliq) by God but does not change creation (Bari). Hathout's assertion begs the question. The biggest question in Islam concerns the application of research findings. Human dignity must be protected from abuse. Thus, the application must be complemented by ethical and sociological studies of possible harms to human beings.

It is believed that the significance of cloning lies in its revelation to humankind as a fundamental reality (Hefner 1997). Thus, human beings are created co-creators and authentic natural creatures making cloned humans be natural persons. Theologically, Hefner contends that life is God's gift, that human beings should be good stewards of God's gifts. Humans are free and accountable to God, and that human experience is inevitably sinful. Policies on cloning have never reflected on those qualities, including allowing considerable time for public discussion, attending to the complex sets of values, and accounting for our fallible judgments.

Jones (1985) argues that cloning is unacceptable to Christians. According to him creativity and change are intrinsic to human life and reflect our likeness of God who is creative and innovative. Cloning by contrast involves replication of the past, and therefore, is a form of "reactionary biological conservatism". The value of clones lies in their replication of characteristics of other persons, clones are valued for others, rather than for themselves. Thus, they are creatures in 'our' likeness, rather than, God's likeness. Jones fears that human cloning will result in lost humanness. In addition, he believes that society is incapable of addressing the ethical issues raised by cloning.

Keown (1975) discusses human cloning from the Buddhist perspective. He reflected on asexual reproduction, which cloning implies. Keown argues that human cloning will merely illustrate the variety of ways that life can be generated which is consistent with the teaching in Buddhist texts. According to him, the Buddhist narrative tradition relates stories of "spontaneous generation" in which sages and supernatural beings have the power to "materialize a human form for themselves at will". In Keown's view, both the clone and the host are ontological individuals entitled to full respect.

Kimbrell (1993) recommends a "complete ban on the cloning of human beings". According to Kimbrell, this ban or policy will be based on an appeal to the "sacred image of the human form" thus, suggesting conceptions of embodiment and the image of God. Lewis (1973) writes on the grave consequences of cloning humans. According to him, the consequences of designing human descendants would be less freedom.

O'Donovan (1984) discusses cloning humans from the Nicene Creed. He uses the Nicene Creed as a point of departure. He contrasts the theological use of 'begotten' with 'making'. He argues that cloning technology demonstrates that mankind does have the awesome technical power to exchange the humanity which God has given him for something else, to treat natural humanity itself as a raw material for constructing a form 
of life that is not natural humanity as an artificial development out of humanity. This implies that the use of scientific capacity comes at the expense of natural humanity.

The article, 'Statement on recent developments in cloning technology' published in 'America' (1997) sums up the view of the Orthodox Church on the subject of cloning. This denominational statement holds that the prospect of human cloning raises the prospect of an ominous slippery slop in which the use of cloning will inevitably lead to abuse. According to them, "Prime" DNA will be commercialized, children will be produced to serve as spare parts, and there will be movements to create a superior race of human beings (Arias 2010). The statement concludes by emphatically requesting that a government ban should be imposed on all forms of experimentation to produce human clones and that government funding for such activity is denied also.

Siegel (1978) addresses the prospects of cloning in the future. He argues that we cannot play God, that humankind is challenged by God to use its reason and imagination and its daring to improve the health and welfare of the human race. Stinson (1972) writes to oppose Ramsey's view. In opposition to Ramsey, Stinson envisions socially regulated cloning of individuals deemed especially valuable to the community within the next century. He offers a key theological concept for the future. The spiritual significance of life lies in the ongoing content of human life, not its origin, whether natural or artificial. He further contends that clones would have a "soul" in as much as they would be capable of personal, ethical, aesthetic, and religious experience. So long as a clone is raised in a loving familiar environment, Stinson believes that there is little question about the genuineness of the humanity of a clone.

\section{PERSONALISM AND PRUDENTIAL PERSONALISM}

Personalism is a modern philosophical principle considered as an improvement of abstract idealism. It conceives life as more than thoughts, more than presentations and ideas (Mullins 1972; Onimhawo 1999). Personalism asserts the accumulative unity of consciousness and recognizes all the facts of consciousness including the will and feelings as well as the intellect. Personalism takes humans in the totality of their relations to nature, to other individuals in human society, and God Himself. It recognizes the common experiences of human beings and the law of reason by which they understand each other and their own experiences.

In a personalist worldview, the ultimate reality is the human person that is a creation of God's hands, endowed with freedom so that the divine person is working out a purpose in human society. Having the goal of history is a perfect society of human beings. With regards to the physical universe or nature, personalism agrees with idealism in the view that nature in all its part is constituted in and for thought, that time and space are forms of thought under which we apprehend the world rather than independent realities (Baca 2014). 
Personalism is a philosophy erected on a broad foundation of facts and experience. Personalism avoids abstraction; hence, it differs from other forms of philosophical reasoning. According to Mullins (1972), personalism takes reality as it finds it and human as the subject. The world is an object for human thoughts. Reality as one knows it includes the subject-object relation. But the object is not a bare-thinker. A human being is an acting person with will, plan, purpose, and a goal of an endeavor. Personalism thus recognizes all that the conception of personality implies and employs it as the type-phenomenon to explain the world of humanity.

On the other hand, personalism is emphatically in its assertion and explanation of first and final causes. Remarkably, physical science knows no 'first cause' hence; all the natural causes are, first of all, the effects of previous causes. Thus, there is only an infinite regress of causes, all of which are on the physical level. Thus: A causes b, and b causes $c$, and $c$ causes $d$, and so it continues indefinitely. This explanation implies that no first cause, that is, no real cause, is ever found by this explanation.

However, personalism asserts that the human 'will' is in a relative sense at least, a first cause, which implies that, from it, humans derive their first and fundamental conception of causation. The human 'will' in this sense is not the result of the transformation of force. It is a cause on a higher level. From here, personalism derives the idea of 'divine will' on an experiential basis. This means, that, the 'will of God' is the moving and efficient cause of all things working toward a divine goal. Human will and knowledge, therefore, are products of God's action - God imparting himself to his creatures.

Prudential personalist ethics is an ethical model whose proponent is B.M. Ashley. This ethics is 'prudential' because it is practical, goal-seeking in character, situational, and contextual. On the other hand, it is 'personalism' in that it evaluates human goals and the means to achieve these goals in terms of the actualization or fulfillment of the human person in his community (Ashley and O'Rourke 1989; Ottuh 2008). This ethical worldview is teleological in principle. It thinks in terms of any actions' effects for the good of persons and the community involved. Accordingly, these effects are, however, evaluated according to needs and purposes that have been established not by subjective preference nor merely by abstract laws, but by the constitution of the human person in its individuality and communal goal (Ashley and O'Rourke 1989). In this sense, prudential personalist ethics proposes that the rightness or wrongness of any human actions can best be judged by considering the indefinite yet teleological goal or end known as 'life' and by asking, how such action in its context contribute to the growth of persons in a community (Waweru 2018). This question can also be answered with the help of what Karl Rahner calls "informed conscience" which the great XX century theologian saw as human's direct contact with the voice of God (Lederer 1994). According to him, people are obligated to inform themselves about ethical norms, incorporate that knowledge into their daily lives, and take responsibility for their actions. 
According to Ashley and O'Rourke (1989), the basic fundamental principles of prudential personalism are that:

- humans need to understand that the Creator has set the goal of human life for all human beings and that to achieve this self-understanding they must use all kinds of information of their conscience;

- effort towards self-understanding does not result in a single principle, but an indefinite number of principles reflecting the complexities and multi-dimensional composition of the human person. In this way, this reflection conveys their system of values, which they need to formulate in the moral values that aid them to make prudent moral choices; and

- in terms of this value system expressed in moral rules, humans strive to inform their consciences covering particular moral choices prudently, by keeping in mind both their goals with priorities and the concrete circumstances, risks, and foreseen special consequences of a particular act. And that such a moral logic is, 'prudential' in its practical, intelligent effort to reach their goals and it is 'personalist' in that it works not for superficial goals but the total realization of inherent needs of the human person in a community.

\section{PRUDENTIAL PERSONALIST APPRAISAL OF HUMAN CLONING}

The act of cloning is a human achievement in the domain of science. This achievement is a result of human thirst and quest for ever greater knowledge which can be considered as one of the tokens of the divine presence in humans working toward the goal of universal well-being and the universal kingdom of truth. Humans' insatiable desire for greater and greater knowledge of nature, its betterment, and nature's response to their quest is both powerful witnesses to God's existence and probable acceptance. The scientific consciousness thus is implicit in it the consciousness of God. It is the consciousness of the finite knower seeking satisfaction in the knowledge of the infinite. Remarkably, since the era of Immanuel Kant, the presence in humans of a moral imperative has been commonplace in philosophical thought (Kant 1966; Zarnadze S, Zarnadze I, Baramidze, Sikharulidze, and Tabidze 2019). This implies that the supreme moral ideal is rooted in every human being, which infers that, human's inventions may probably not be devoid of morality since human is divinely moral conscious.

As earlier stated, the prudential personalist ethical model proposes that the rightness or wrongness of any action should be judged based on its communal goals and good. In this sense, such goals or consequences resulting from an act must be evaluated only in terms of the actualization of the human person as it relates to other human persons. This means that the consequences of human action must not be evaluated in terms of immediate pains and pleasure or any other quantitative values as the case may be. 
According to this ethics, there are inherent finalities in a human being which they do not have the power or right to choose. For example, no human being has the power to choose to become human. Human beings are human beings because God made them so. As such, human life is considered a gift from God (Wilson 2014). This ethical argument is synonymous with the assertion of the German philosopher, Immanuel Kant who says that human beings must be treated as ends in themselves, not as means to an end. This is a principle that forms the basis for many human cloning debates. Perhaps, the starkest application of such reasoning is the possibility that humans may be cloned to provide human spare parts (organs) that could be transplanted into the genetic donor without fear of rejection. The use of cloned embryos and fetuses for such purposes is defended by some cloning advocates and dismissed by others based on human 'personalism', and this makes it a far-fetched scenario that can never come to reality. However, many will agree that creating a clone of a person simply as a source of 'spare parts' is a gross violation of Kant's principle and the prudential personalist ethical model.

It should be admitted here that although one may agree with Kant's principle of rationality and responsibility as well as Ashley and O'Rourke's prudential personalism, and also believe that this kind of mixed ethics 'duty ethics' and 'means-ends ethics' are aimed at directing humanity responses to the good of persons in a community. This kind of ethics can also be called the ethics of 'Genuine Human Realization' (Isiramen and Akhilomen 1998). In prudential personalist ethics; one may determine genuine human goals not based on relativism or subjectivism, but based on the human persons which are patterned to the historical Jesus Christ who is believed to be the highest measure of morality.

The ethical questions people have raised about human cloning exist on several levels. In applying the prudential personalist principle, one may, first of all, determine the humanity of a clone. Others may go further and argue that cloning for any purpose violates Ashley's ethics on some level because a 'manufactured' child or person would be burdened by specific expectations on what kind of human person a clone (child) would become. Admittedly, there must be a profound ethical difference between having a child by natural conception and making a child through cloning (Ashley and O'Rourke 1989; Ottuh 2008). For instance, a child begotten can always be seen as a gift, whereas, a child made or manufactured can always be seen as a 'thing' - a product for use not to be respected for his human uniqueness, but could be priced for what it can do (MacDonagh 1975; Ottuh 2020). However, others have rejected the argument that just because a person is a clone, he or she would not be treated and loved as any other human person would be treated.

The ethical question here is that whether one should treat a clone as a normal human person or whether a clone meets certain criteria used in evaluating the idea of a human person. Biologically, the origin of human life is another human life (Ottuh 2020). 
This means life proceeds from another life through natural conception or reproduction. Given the aforementioned, human cloning is artificial, thus attracting the potentiality of putting a clone into the realm of a sub-human, hence a cloned person can be subjected to unfair expectations. How would a prudential personalist judge the action of a couple involved or who contemplates cloning to have children?

For instance, people might deem it ethical or prudential for a couple at risk of bearing children with a genetic disorder to clone one of the healthy parents. But would it be ethical for a couple to clone a child simply because the father desired a genetic replica of such child? Again, would it be ethical for parents to take cells from a child who died suddenly in an accident and clone them for 'replacement' since that second child could be subjected to unfair expectations? Next, would society have any right to intrude on the reproductive decisions of couples and individuals by imposing any restrictions on cloning? Here, a definition of human needs will give answers to these questions especially from the context of prudential personalist ethics. In this sense, the definition of human needs gives an empirical overview of what a human person is.

Human needs are not merely static facts but are goals to be achieved. Hence, they become values, that is, goods to be desired. To attain these needs there must be an interplay of human intelligence, freedom, and creativity. In this sense, human needs become a value system. In this wise, ethical decisions are always taken within the context of some value system. Judging the phenomenon of human cloning within the context of prudential personalist ethics, the value systems of others must be taken into account. In support of this view, the prudential personalist ethics prompt one to think in terms of the consequences of any action for the good of the person and the community involved, but it evaluates these consequences in terms of needs and purposes which have been established not by subjective preference, nor more by abstract Laws but the constitution of the human person in its individual and communal dynamism.

At this juncture, the fact should be clearly stated, that the ethical issue involved in human cloning should not be whether it is ethical to clone humans, but whether human cloning is ethical in improving the quality of human life or to create human life. One fact remains, that is, every human person has the ethical, biological, and sociological rights to be disposed to the usage of his or her freedom. This too is a gift from God considered in their totality as a system of needs and genetically inherent requirements of life becoming genuinely obligatory because humans need to be themselves and to achieve self-realization. Viewing human cloning from its ethical-communal perspective, the technology may not find favor in prudential personalist ethics. 


\section{CONCLUSION}

It is agreed in this paper that diverse issues are facing medical ethicists and religious groups in contemporary times, such as advances in cloning technology, new knowledge of the human brain, and the wealth of genetic data.

Perhaps no event in biotechnology has caused more uproar and bioethical discussion than the cloning of Dolly the Sheep in 1997 hence today clinical studies continue to present bioethical challenges. A critical look at cloning shows possible significant effects on developing research in the sense of cloning for commercial purposes to improve humanity through genetic manipulation. Although these achievements and benefits may not be the first of new technology, it certainly has that potential. Human cloning taps into our vivid fears about the reproduction of evil beings for evil purposes. Cloning humans is a stock issue for science fiction. And indeed some of the scenarios that could be imagined are all quite awful, for instance cloning a copy of oneself that will serve as 'spare parts.'

The insurmountable moral problem with that scenario is that one's clone would be a person, not just one's property. In this sense, one could no more justify taking his or her vital organs than demanding the same from one's identical twins. In grasping the relevance of prudential personalist ethics as an ethical underlying model, the sanctity and respect for human life is a sine-qua-non. Using the prudential personalist ethics to appraise the morality of human cloning reveals that every human life has worth hence its commodification amounts to an aberration. This ethical-theological principle conceives human life solely as a part of the human community pursuing communal goals. Therefore, cloning human beings (especially, human reproductive cloning) negates respect for human life, human dignity, and the communal goals of the human community. 


\section{REFERENCES}

1. Anderson, J.K. (1982). Genetic Engineering. Grand Rapids, M1: Zondervan Publishing House

2. Annas, G.J., Andrews, L.B. \& Isasi, R.M. (2002). Protecting the Endangered Human: Toward an International Treaty Prohibiting Cloning and Inheritable Alterations. American Journal of Law and Medicine, 28(2), 151-178.

3. Appleyard, B. (1998). Brave New Worlds: Staying Human in the Genetic Future, New York: Viking

4. Arias, E. (2010). United States Life Tables. Nat/ Vital Stat Rep, 58(21), 1-40.

5. Ashley, B.M. and O'Rourke, K.D. (1989). Health Care Ethics: A Theological Analysis. St. Louis, Missouri: The Catholic Hospital Association

6. Ayala, F.J. (2015). Cloning Humans? Biological, Ethical, and Social Considerations. PNAS, 112 (29), 8879-8886.

7. Baca, F. (2014). Philosophical Worldviews on the Nature of Thinking and Acting. European Scientific Journal, ESJ, 10(20).

8. Begley, S. (March 15, 1997). Cloning: Now Man Begins to Play God. Sunday Vanguard.

9. Benoit, B. (March 3, 1996). Why Clone Human Embryos. The New York Times, 96.

10. Breeck, J. (1991). Genetic Engineering: Setting the Limits. In Chirban, J.T. (ed.). Health and Faith: Medical, Psychological and Religious Dimensions (pp. 6381). Washington, DC: University Press of America.

11. Brown, R.G. (1995). Clones, Chimeras and the Image of God: Lessons from Barthian Ethics. In Kilnier, J.F., Cameron, N.M., \&Scheidermayer, D.L. (eds.). Bioethics and the Future of Medicine: A Christian Appraisal (pp. 232-241). Grand Rapids, Ml: Win. B. Eerdmans Publishing Company.

12. Campbell, C.S. (2002). Cloning Human Beings: Religious Perspectives on Human Cloning. A Paper Presented to U.S. National Bioethics Advisory Commission, Oregon State University.

13. Campbell, K.H.S., Wilmut, I., Schnieke, A.E., McWhir, J. \&Kind, A.J. (Feb. 27, 1997). Viable offspring derived from fetal and adult mammalian cells. Nature Magazine, 199.

14. Catholic Leadership Conference. (2001). Statement of the Catholic leadership conference on human cloning. Retrieved from: www.priestsforlife.org/articles/0111-01humancloningele.htm

15. Christodoulou, I. (2014). Philosophy's Humanistic Dynamism. European Scientific Journal, ESJ, 10(10).

16. Cole-Turner, R, (ed.) (1997). Human Cloning: Religions Perspective. Louisville, KY: West Minister John Knox.

17. Cooke, R. (1997). Improving on Nature. New York: Quadrangle Press. 
18. Daley, G.Q. and Solbakk, J.H. (2011). Stem Cells: Triple Genomes Go Far. Nature, 478 (7367), 40-61.

19. Duff, N.J. (March 2, 1997). Clone with Caution. The Washington Post.

20. Enwere, U.M. (2002). Introduction to Human Rights: The Role of the Police in the Protection of Human Rights. In Ovienloba, A. (ed.). Democracy and Human Rights in Nigeria: Issues and Perspectives. Benin: JDPC.

21. Fletcher, J. (1979). Humanhood: Essays in Biomedical Ethics. Buffalo, NY: Prometheus Books.

22. Flock, A. (2007). Who is Richard Seed? Retrieved from: www.cnn.com/CNN/bureaus/Chicago/Stories/9801/coning-doc/index.Htm.

23. Hathout, M. (March 8, 1997). Cloning: Who Will Set the Limits? The Minaret 19(3), 98.

24. Hawley, A. (1997). Cloning. Compton's Interactive Encyclopedia.Oxford: Clareudo Press.

25. Hefner, P. (1997). Cloning as Quintessential Human Act. Insights, 273.

26. Isiramen, C.O. \&Akhilomen, D.O. (1998). Essays in Philosophy of Religion, Ethics, and Early Church Controversies. Lagos: AB Associate Publishers.

27. Jones, D.G. (1985). Brave New People: Ethical Issues at The Commencement of Life. Grand Rapids, MI: Win B. Eerdmans Publishing.

28. Kant, I. (1966). Critiques of Pure Reason. New York: Anchor Books.

29. Keown, D. (1995). Buddhism and Bioethics. New York: St. Martins Press.

30. Kimbrell, A. (1993). The Human Body Shop: The Engineering and Marketing of Life. New York: Harper Collins Publishers.

31. Kolata, G. (Feb. 23, 1997). Clinton's Paul Backs Moratorium on Human Cloning. The New York: Times.

32. Lederer, T. (1994). Health Care Ethics: Theological and Papal Perspectives. Hunting, NY: The Immaculate Conception Seminary.

33. Lewis, C.S. (1973). The abolition of Man. New York: Macmillan.

34. Liu, Z., Cai, Y., Wang, Y., Nie, Y., Zhang, C., Xu, Y. \&Qiang, Y. (2018). Cloning of macaque monkeys by somatic cell nuclear transfer. Cell, 172 (4), 881-887.

35. Lynn, B. (1973). Genetic Manipulation. New York: Macmillan Pub.

36. McCormick, J.S. \& Richard, R. (1981). How Brave a New World: Dilemmas in Bioethics. Garden City, NY: Doubleday and Company.

37. McDonagh, E. (1975). Gift and Call towards a Christian Theology of Morals. St. Meinrad, Ind.: Abbey Press.

38. McLaren, A. (2000). Cloning: Pathways to a Pluripotent Future. Science, 288(5472), 1775-1780.

39. MicKinnell, E.G. (1977). Cloning: A Biologist Report. Minneapolis: University of Minnesota Press. 
40. Mullins, E. Y. (1972). The Christian Religion in Its Doctrinal Expression. London: Judson Press.

41. National Academy of Science, Committee on Science (2002).Engineering and Public Policy: Scientific and Medical Aspects of Human Reproductive Cloning. Retrieved from: www.aaas.org/spp/csts/pne/pubs/cloningreport.pdf

42. National Pro-Life Religions Council. (2007). Statement on Human Cloning. Retrieved from: www.oprcouncil.org/pressreleases/cloning/nprc.htm

43. O'Donovan, O. (1984). Begotten or Made? Oxford: Clareudo Press.

44. Onimhawo, J.A. (1999). Ethical Medical and Legal Perspective on Euthanasia. Ibadan: Stirling-Ho den Publishers.

45. Ottuh, P.O.O. (2008). Human Cloning: A Philosophico-Theological Appraisal. (Unpublished PhD Thesis). Ekpoma: Ambrose Alli University.

46. Ottuh,P.O.O. (2010a). The Inhumanity of Human Cloning: An Ethico-Theological Evaluation. The Humanities Journal: An International Journal of Research and Development, 1(1), 1-15.

47. Ottuh, P.O.O. (2010b). Arguments about Human Cloning in Perspectives. Ife Journal of Religions, 6 (1\&2), 126-148.

48. Ottuh, P.O.O. (2010c). Clono-theodicy: A Biblico-Qur'anic Defence of God in The 'Cloning' of Adam and Eve. In Chepkwony, A.K. \& Hess, P.M.I. (Eds.), Human Views on God: Variety not Monotony (pp. 241-249). Kenya: Moi University Press.

49. Ottuh, P.O.O. (2010d). Feminism and Human Cloning: Towards a Defence of Women's Selfhood. In Ukagba, G.U. (Ed.). The Kpim of Feminism: Issues and Women in a Changing World (pp. 62-83). Canada: Trafford Publishing.

50. Ottuh, P.O.O. (2020). Assessing Human Reproductive Cloning and Creationism from the

51. Perspectives of Raelianism and African Belief. Jurnal Office,6 (1), 81-96.

52. Polkinghorne, J. (1997). Cloning and the Moral Imperative. In Cole-Turne, R. (Ed.). Human Cloning: Religious Responses. Louisville: Westminster John Knox Press.

53. Post, S.G. (1997). The Judeo -Christian Case on Cloning. American, 21.

54. Qiu, R. (1997). The Moral Implications of Cloning. Journal of Dialectics of Nature, 13 (6), 202.

55. Ramsey, P. (1970). Fabricated Man: The Ethics of Genetic Control. New Haven, CT: Yale University Press.

56. Rorvik, D.M. (1978). In His Image: The Cloning of a Man. Philadelphia: J.B. Lippimcott.

57. Shannon, T.A. (1994). Cloning, Uniqueness, and Individuality. Lonvain Studies, 19 (42), 233.

58. Shelp, E.E. (Eds.) (1986). Theology and Bioethics: Exploring the Foundations and Frontiers. Baldachin: D. Reidel. 
59. Siegel, S. (1978). Genetic Engineering: Some Reflections. In Ebon, M. (Ed.). The Cloning of Man: A Brave New Hope or Horror. New York: Signet Books.

60. The President's Council on Bioethics: Working Paper 3b. (2007). Retrieved from: www.bioethics.gov/background/workingpaper3b.htm/

61. Thomas, I. (2013). Should Scientists Pursue Cloning? London: Raintree.

62. Tugnoli, C. (2016). Theodicy of Jean-Jacques Rousseau. European Scientific Journal, ESJ, 12(29), 10.

63. United Nations Educational, Scientific, and Cultural Organization (UNESCO). (2006). Universal declaration on the human genome and human rights. Retrieved from: www.umn.edu/humananrts/instree/Udhrhg.htm

64. Verhey, A.D. (1994). Cloning: Revisiting an Old Debate. Kennedy Institute of Ethics Journal,4 (3), 227-254.

65. Waweru, H. M. (2018). African Theology in the 21st Century: Mapping Out Critical Priorities. European Scientific Journal, ESJ, 14(8), 213.

66. Wills, C. (Jan. 22, 1998). A Sheep in Sheep's Clothing? Discover, 131.

67. Wilson, E.O. (2014). The Meaning of Human Existence. New York: Liveright

68. World Council of Churches (WCC). (1982) Manipulating life: Ethical issues in genetic engineering. Geneva: WCC.

69. Zahir, I. I. (2016). Hippocrates: Philosophy and Medicine. European Scientific Journal, ESJ, 12(26), 199.

70. Zarnadze, S., Zarnadze, I., Baramidze, L., Sikharulidze, Z., Tabidze, D., \& Bakradze, T. (2019). Problem Base and Case Study Methodology in Medical Education. European Scientific Journal, ESJ. Retrieved from https://eujournal.org/index.php/esj/article/view/12904

71. Zoloth, I. \& Holland, S. (Eds.) (2001). The Human Embryonic Stem Cell Debate: Science, Ethics, and Debate: Science, Ethics and Public Policy. U.S.A: MIT Press. 